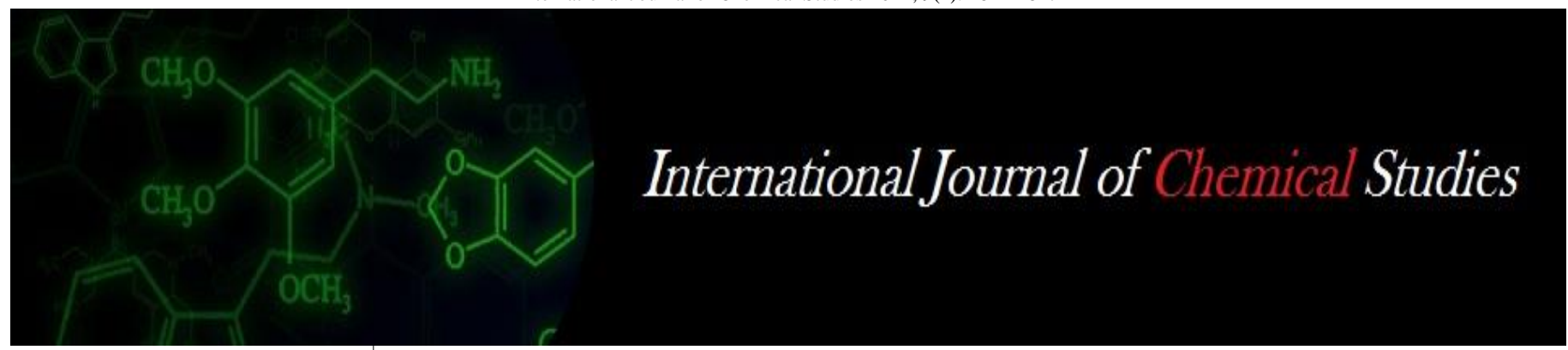

P-ISSN: 2349-8528

E-ISSN: 2321-4902

www.chemijournal.com

IJCS 2021; 9(1): 2844-2847

(C) 2021 IJCS

Received: 08-10-2020

Accepted: 19-11-2020

Baijayanti Nayak

1. Department of Agronomy, College of Agriculture, Odisha University of Agriculture \& Technology, Bhubaneswar, Odisha, India

2. ICAR - National Rice Research Institute, Cuttack, Odisha, India

BS Rath

Department of Agronomy, College of Agriculture, Odisha

University of Agriculture \&

Technology, Bhubaneswar,

Odisha, India

M Shahid

ICAR - National Rice Research

Institute, Cuttack, Odisha, India

SN Jena

Department of Agronomy, College of Agriculture, Odisha

University of Agriculture \&

Technology, Bhubaneswar,

Odisha, India

Ashirbachan Mahapatra

1. ICAR - National Rice

Research Institute, Cuttack,

Odisha, India

2. Department of Agronomy, College of Agriculture, Indira Gandhi Krishi

Vishwavidyalaya, Raipur,

Chhattisgarh, India

Sanjoy Saha

ICAR - National Rice Research Institute, Cuttack, Odisha, India

Corresponding Author:

Sanjoy Saha

ICAR - National Rice Research

Institute, Cuttack, Odisha, India

\section{Effect of organic nutrient management on plant growth, productivity and economics of aromatic rice}

\author{
Baijayanti Nayak, BS Rath, M Shahid, SN Jena, Ashirbachan Mahapatra \\ and Sanjoy Saha
}

DOI: https://doi.org/10.22271/chemi.2021.v9.i1an.11654

\begin{abstract}
A field experiment was carried out during kharif seasons of 2015 and 2016 at Agronomy Research Farm, Central Research Station, Odisha University of Agriculture and Technology, Bhubaneswar, Odisha, to study the effect of organic nutrient management on plant growth, productivity and economics of aromatic rice. Application of recommended dose of fertilizer to aromatic rice (Geetanjali) produced improved plant growth with higher grain and straw yield having higher net return with $\mathrm{B}: \mathrm{C}$ ratio. Among organic treatments, similar plant growth, yield and profit also obtained with application of $100 \%$ recommended dose of nitrogen through poultry manure along with top dressing with liquid manure twice at 25 and 50 days after transplanting.
\end{abstract}

Keywords: Aromatic rice, poultry manure, growth, yield, economics

\section{Introduction}

The area under aromatic rice varieties is increasing day by day with the opening of the world market as well as increased domestic consumption due to their superior cooking and eating quality ${ }^{[1]}$. Simultaneously, organic rice is also gaining importance in world market. At present, the farmers cultivate such premium aromatic rice in native areas following chemical-based agricultural practices, which has led to increased productivity but has adversely affected the grain quality, soil health and environment. However, organic nutrient management in rice is getting much attention in present-day agricultural system due to increased demand for organic foods. Moreover, Murali and Setty ${ }^{[2]}$ reported that organic manures improved the quality of aromatic rice. Geetanjali is a long slender aromatic rice variety mainly cultivated in Mahanadi river belts of Odisha. It is very popular in market for preparation of polao, biryani as well as for making, payash (dessert) etc. To promote organic cultivation of Geetanjali rice in Odisha, the present investigation aims to identify the best suitable organic nutrient management practice for higher productivity and economic return in aromatic rice.

\section{Materials and Methods}

The experiment was carried out at the Agronomy Research Farm, Central Research Station, Odisha University of Agriculture and Technology, Bhubaneswar during kharif seasons of 2015 and 2016. The soil property of the experimental site was sandy loam (72.3\% sand, $11.5 \%$ silt and $16.2 \%$ clay) with slightly acidic in reaction ( $\mathrm{pH} 5.92)$, medium in organic carbon (0.52\%), low in available $\mathrm{N}(247.21 \mathrm{~kg} / \mathrm{ha})$, high in available $\mathrm{P}_{2} \mathrm{O}_{5}(44.38 \mathrm{~kg} / \mathrm{ha})$ and medium in $\mathrm{K}_{2} \mathrm{O}$ content (168.84 kg/ha). Sixteen treatments consisting of fourteen organic from three different sources either alone or its combination as well as one inorganic and one control without organic or inorganic, viz. $\mathrm{T}_{1}: 100 \%$ Recommended Dose of Nitrogen (RDN) through Farm Yard Manure (FYM), $\mathrm{T}_{2}: 100 \%$ RDN through Concentrated manure (CM), $\mathrm{T}_{3}: 100 \% \mathrm{RDN}$ through Poultry manure (PM), $\mathrm{T}_{4}: 50 \%$ RDN through FYM + 50\% RDN through CM, $\mathrm{T}_{5}: 50 \%$ RDN through FYM + 50\% RDN through PM, T $6: 50 \%$ RDN through $\mathrm{CM}+50 \%$ RDN through $\mathrm{PM}, \mathrm{T}_{7}: 1 / 3^{\text {rd }} \mathrm{RDN}$ through FYM $+1 / 3^{\text {rd }} \mathrm{RDN}$ through $\mathrm{CM}+1 / 3^{\text {rd }} \mathrm{RDN}$ through PM, $\mathrm{T}_{8}: \mathrm{T}_{1}+$ $\mathrm{TD}\{$ Top dressing with Liquid manure twice at 25 and 50 Days after transplanting (DAT) $\}, \mathrm{T}_{9}$ : $\mathrm{T}_{2}+\mathrm{TD}, \mathrm{T}_{10}: \mathrm{T}_{3}+\mathrm{TD}, \mathrm{T}_{11}: \mathrm{T}_{4}+\mathrm{TD}, \mathrm{T}_{12}: \mathrm{T}_{5}+\mathrm{TD}, \mathrm{T}_{13}: \mathrm{T}_{6}+\mathrm{TD}, \mathrm{T}_{14}: \mathrm{T}_{7}+\mathrm{TD}, \mathrm{T}_{15}:$ 
Recommended Dose of Fertilizer (RDF) (80:40:40 kg $\mathrm{N}: \mathrm{P}: \mathrm{K} / \mathrm{ha}), \mathrm{T}_{16}$ : Control without organic or inorganic were laid out in randomized block design in three replicates.

Of the three different sources of organic manure i. e. FYM, $\mathrm{PM}$ and $\mathrm{CM}$, the first two were collected from different sources and the third one was self-prepared. The liquid manure (LM) "Sanjivak" was also self-prepared following the procedure given by Yadav ${ }^{[3]}$. The nutrient composition of these organic manures (FYM, CM, PM and LM) are 0.580.31-0.58, 2.1-1.32-1.71, 2.24-2.3-2.1, 0.57-0.06-0.37\% N-P$\mathrm{K}$, respectively. From these organic manures FYM, PM and $\mathrm{CM}$ were incorporated as per the standard treatments i.e. one day before transplanting in the puddled field. The recommended dose of fertilizers (RDF) i.e. 80-40-40 kg NPK/ha were applied through urea, single super phosphate and murate of patash. Half of the $\mathrm{N}$ and full of $\mathrm{P}$ and $\mathrm{K}$ were applied at the time of puddling while remaining $\mathrm{N}$ was applied in three equal splits i.e. at early tillering, late tillering and panicle initiation stage. Twenty-five days old seedlings of "Geetanjali" aromatic rice were transplanted in the main experimental field on $14^{\text {th }}$ and $19^{\text {th }}$ August in kharif during 2015 and 2016, respectively, at a spacing of $20 \mathrm{~cm} \times 10 \mathrm{~cm}$. Under growth parameters, plant height, leaf area index and dry matter production were recorded at 90 DAT. After harvest of the crop, grain yield and yield attributing characters viz. panicles $/ \mathrm{m}^{2}$, panicle length, grains/panicle, sterility percentage, 1000 grain weights were determined and economics was calculated as per the prevailing market values. The data were subjected to the Analysis of Variance using the Statistical Analysis System (SAS) and significant differences among the treatment means tested Fisher's protected Least Significant Difference (LSD) test at $\mathrm{p} \leq 0.05$.

\section{Results and Discussion Growth}

The data presented in the Table 1 clearly pointed out that the rice plants supplied with inorganic source produced tallest plants $(118.3 \mathrm{~cm})$, highest leaf area index (4.36) and the highest dry matter per plant $60.9 \mathrm{~g} / \mathrm{hill}$ at 90days after transplanting. The rate of increase in dry matter accumulation was almost 1g/day. Among organic treatments, maximum height of the plant $(115.3 \mathrm{~cm})$ and dry matter accumulation $(60.7 \mathrm{~g})$ were obtained by the crop supplied with poultry manure with liquid manure top dressed twice at 25 and 50 DAT $\left(\mathrm{T}_{10}\right)$, which was found at par with height and dry matter obtained from crop supplied with sole poultry manure $\left(\mathrm{T}_{3}\right)$ and concentrated manure alone $\left(\mathrm{T}_{2}\right)$ or in combination with liquid manure top dressed twice at 25 and 50 DAT $\left(\mathrm{T}_{9}\right)$ during both the year. The increase in plant height as a result of chemical fertilizer application might be primarily due to the improved vegetative growth and additional subscription of nitrogen ${ }^{[4]}$. Besides, Hasanuzzaman et al. ${ }^{[5]}$ opined that the variation in plant height due to application of different nutrient sources was a result of differential availability of major nutrients. The leaf area index increased progressively with advancement of the age of the crop up to 75 DAT and declined thereafter. From the data it was evident that highest leaf area index (4.36) was recorded from the crop supplied with chemical fertilizer which is significantly different from the LAI (4.14) recorded from the best organic practices during the study period. The superiority of chemical fertilizer in manifesting higher LAI was mostly due to higher availability of major nutrients while among the organic sources, the superiority of poultry manure (PM) was justified because of higher decomposition rate of PM as compared to FYM.

Table 1: Plant height $(\mathrm{cm})$, Leaf Area Index and Dry matter production $(\mathrm{g} / \mathrm{hill})$ at 90 days after transplanting in aromatic rice as influenced by organic nutrient management (Mean of 2 years)

\begin{tabular}{|c|c|c|c|}
\hline Treatments & Plant height $(\mathbf{c m})$ & Leaf Area Index & Dry matter production (g/hill) \\
\hline $\mathrm{T}_{1}: \mathrm{FYM} 100 \% \mathrm{RDN}$ & 108.5 & 3.83 & 50.6 \\
\hline $\mathrm{T}_{2}: \mathrm{CM} 100 \% \mathrm{RDN}$ & 112.7 & 4.00 & 56.9 \\
\hline $\mathrm{T}_{3}: \mathrm{PM} 100 \% \mathrm{RDN}$ & 113.3 & 4.10 & 60.6 \\
\hline $\mathrm{T}_{4}: \mathrm{FYM} 50 \% \mathrm{RDN}+\mathrm{CM} 50 \% \mathrm{RDN}$ & 106.4 & 3.72 & 47.2 \\
\hline T5: FYM 50\% RDN+PM 50\% RDN & 109.5 & 3.88 & 51.9 \\
\hline $\mathrm{T}_{6}: \mathrm{PM} 50 \% \mathrm{RDN}+\mathrm{CM} 50 \% \mathrm{RDN}$ & 111.2 & 3.94 & 53.3 \\
\hline $\mathrm{T}_{7}: \mathrm{FYM} 1 / 3^{\text {rd }} \mathrm{RDN}+\mathrm{CM} 1 / 3^{\text {rd }} \mathrm{RDN}+\mathrm{PM} 1 / 3^{\text {rd }} \mathrm{RDN}$ & 106.9 & 3.75 & 47.5 \\
\hline T8: T1+Top dressing with liquid manure & 109.3 & 3.86 & 52.0 \\
\hline T9: T2+Top dressing with liquid manure & 112.7 & 4.03 & 57.4 \\
\hline $\mathrm{T}_{10}$ : T3+Top dressing with liquid manure & 115.3 & 4.14 & 60.7 \\
\hline $\mathrm{T}_{11}$ : T4+Top dressing with liquid manure & 107.7 & 3.78 & 47.7 \\
\hline $\mathrm{T}_{12}$ : T5+Top dressing with liquid manure & 110.6 & 3.91 & 52.5 \\
\hline $\mathrm{T}_{13}$ : T6+Top dressing with liquid manure & 111.9 & 3.97 & 54.0 \\
\hline $\mathrm{T}_{14}$ : T7+Top dressing with liquid manure & 108.2 & 3.80 & 49.2 \\
\hline $\mathrm{T}_{15}: 80: 40: 40 \mathrm{RDF}$ & 118.2 & 4.36 & 60.9 \\
\hline $\mathrm{T}_{16}$ : Control & 103.6 & 3.45 & 44.2 \\
\hline S.Em \pm & 2.13 & 0.03 & 1.41 \\
\hline $\mathrm{CD}(\mathrm{P}=0.05)$ & 6.14 & 0.08 & 4.08 \\
\hline
\end{tabular}

\section{Yield and yield attributes}

Data on yield and yield attributing characters are presented in Table 2 which revealed that organic nutrient management also had a positive effect on yield attributes over control. Again application of recommended dose of fertilizer $\left(T_{15}\right)$, resulted highest yield attributing characters like tiller $/ \mathrm{m}^{2}$ (459.01), panicle length $(26.55 \mathrm{~cm})$, grains/panicle $(122.52)$ and 1000 grain weight $(22.95 \mathrm{~g})$ with lowest sterility percentage $(6.84)$ which was superior to all other treatments. Among various organic sources, application of poultry manure in combination with liquid manure twice at 25 and 50 DAT $\left(\mathrm{T}_{10}\right)$, resulted maximum tiller $/ \mathrm{m}^{2}$ (395.97), panicle length $(26.31 \mathrm{~cm})$, grains/panicle (106.45) and 1000 grain weight (22.88 g). The crop received neither inorganic nor organic sources of nutrients (Control, $\mathrm{T}_{16}$ ) produced lowest yield and yield attributing characters. Increased production of tillers $/ \mathrm{m}^{2}$ and filled grains in rice obtained through the application of enriched poultry manure or composted poultry manure was also reported earlier by Sangeetha et al. ${ }^{[6]}$.

Yield is the better manifestation of growth and yield attributing characters (Table 2). During both the years of study, yield outcomes from the organic treatments were 
higher than the control $\left(\mathrm{T}_{16}\right)$, but lower than the inorganic sources of fertilizer application $\left(\mathrm{T}_{15}\right)$. Application of liquid manure twice at 25 and 50 DAT marginally improved the growth and yield of rice. Application of such liquid manure extended the leaf area duration that sufficed the nutrient requirement during the latter part of crop growth and ensured better partitioning of photosynthates from the source to the sink ${ }^{[7]}$. But interestingly the yield obtained from Gitanjali rice when supplemented with organic sources like PM and CM either in sole or in combination were almost at par with the yield recorded from the rice crop grown inorganically during the period of study. The advantage of PM than other sources of organic manures was also registered earlier in a clay loam soil of Bapatla, Andhra Pradesh ${ }^{[8]}$ and the advantage of inorganic sources over the organic sources of fertilizer was reported by Kumari et al. ${ }^{[9]}$.

Table 2: Yield attributes, Grain yield (t/ha) and Harvest index of aromatic rice as influenced by organic nutrient management (Mean of 2 years)

\begin{tabular}{|c|c|c|c|c|c|c|c|c|}
\hline Treatments & $\begin{array}{c}\text { No. of } \\
\text { Panicles } \\
/ \mathbf{m}^{2} \\
\end{array}$ & $\begin{array}{c}\text { Panicle } \\
\text { length } \\
(\mathrm{cm})\end{array}$ & $\begin{array}{c}\text { Sterility } \\
\text { percentage } \\
(\%)\end{array}$ & $\begin{array}{c}\text { No. of } \\
\text { Grains/ } \\
\text { Panicle }\end{array}$ & $\begin{array}{l}1000 \text { grain } \\
\text { weight (g) }\end{array}$ & $\begin{array}{l}\text { Grain } \\
\text { Yield } \\
(\mathrm{t} / \mathrm{ha}) \\
\end{array}$ & $\begin{array}{c}\text { Straw } \\
\text { yield } \\
\text { (t/ha) } \\
\end{array}$ & $\begin{array}{c}\text { Harvest } \\
\text { Index }\end{array}$ \\
\hline $\mathrm{T}_{1}: \mathrm{FYM} 100 \%$ RDN & 335.06 & 24.72 & 18.50 & 88.36 & 22.49 & 3.50 & 5.42 & 39.24 \\
\hline $\mathrm{T}_{2}: \mathrm{CM} 100 \% \mathrm{RDN}$ & 354.76 & 25.32 & 13.69 & 100.27 & 22.68 & 3.72 & 6.08 & 37.92 \\
\hline T3: PM 100\%RDN & 377.58 & 26.24 & 11.80 & 104.52 & 22.86 & 3.98 & 6.23 & 38.98 \\
\hline T4: FYM 50\%RDN+CM 50\%RDN & 298.78 & 24.32 & 23.57 & 79.24 & 22.25 & 3.27 & 4.97 & 39.67 \\
\hline $\mathrm{T}_{5}: \mathrm{FYM} 50 \%$ RDN+PM 50\% RDN & 341.47 & 24.98 & 15.70 & 94.28 & 22.55 & 3.57 & 5.73 & 38.42 \\
\hline $\mathrm{T}_{6}:$ PM 50\% RDN+CM 50\% RDN & 348.03 & 25.25 & 14.90 & 95.81 & 22.64 & 3.67 & 6.00 & 37.93 \\
\hline $\mathrm{T}_{7}: \mathrm{FYM} 1 / 3^{\text {rd }} \mathrm{RDN}+\mathrm{CM} 1 / 3^{\text {rd }} \mathrm{RDN}+\mathrm{PM} 1 / 3^{\text {rd }} \mathrm{RDN}$ & 318.48 & 24.35 & 22.17 & 79.24 & 22.35 & 3.32 & 4.99 & 39.96 \\
\hline$T_{8}: T_{1}+$ Top dressing with liquid manure & 338.51 & 24.75 & 16.87 & 88.42 & 22.51 & 3.54 & 5.66 & 38.46 \\
\hline$T_{9}: T_{2}+$ Top dressing with liquid manure & 374.30 & 25.55 & 12.51 & 102.06 & 22.83 & 3.75 & 6.10 & 38.03 \\
\hline $\mathrm{T}_{10}: \mathrm{T}_{3}+\mathrm{Top}$ dressing with liquid manure & 395.97 & 26.31 & 10.96 & 106.45 & 22.88 & 4.17 & 6.44 & 39.30 \\
\hline $\mathrm{T}_{11}: \mathrm{T}_{4}+\mathrm{Top}$ dressing with liquid manure & 325.21 & 24.55 & 21.12 & 81.04 & 22.43 & 3.42 & 5.34 & 39.06 \\
\hline $\mathrm{T}_{12}: \mathrm{T}_{5}+\mathrm{Top}$ dressing with liquid manure & 344.09 & 25.25 & 15.13 & 95.54 & 22.62 & 3.59 & 5.83 & 38.11 \\
\hline $\mathrm{T}_{13}: \mathrm{T}_{6}+\mathrm{Top}$ dressing with liquid manure & 351.32 & 25.28 & 13.83 & 96.27 & 22.67 & 3.70 & 6.03 & 38.01 \\
\hline $\mathrm{T}_{14}: \mathrm{T}_{7}+\mathrm{Top}$ dressing with liquid manure & 328.33 & 24.62 & 18.85 & 83.30 & 22.46 & 3.44 & 5.36 & 39.10 \\
\hline $\mathrm{T}_{15}: 80: 40: 40 \mathrm{RDF}$ & 459.01 & 26.55 & 6.84 & 122.52 & 22.95 & 4.19 & 6.51 & 39.17 \\
\hline $\mathrm{T}_{16}:$ Control & 275.80 & 23.82 & 25.22 & 72.65 & 22.09 & 2.48 & 4.83 & 33.89 \\
\hline S.Em \pm & 16.33 & 0.47 & 3.01 & 10.11 & 0.23 & 0.19 & 0.31 & 1.71 \\
\hline $\mathrm{CD}(\mathrm{P}=0.05)$ & 47.15 & 1.36 & 8.70 & 29.19 & 0.65 & 0.55 & 0.91 & 4.94 \\
\hline
\end{tabular}

Among the organic treatment crop receiving PM along with top dressing twice with liquid manure $\left(\mathrm{T}_{10}\right) \quad 17.9 \%$ higher yield over FYM 100\% RDN + TD with liquid manure and at par with the yield recorded from PM 100\% RDN, CM 100\% RDN, CM 100\% RDN + TD with liquid manure. Higher nutrient content and steady nutrient release pattern of poultry manure and concentrated manure enhanced the yield of aromatic rice compared to FYM.

Devegowda ${ }^{[10]}$ reported that the superiority of poultry manure was mostly because it contains both urinary and fecal excretions which lead to three times more nutrient value than FYM. Harvest Index (HI) is the indication of the quantum of partitioning of photosynthates from vegetative towards the reproductive part of the plant. The influence of nutrient management on $\mathrm{HI}$ of rice was found at par in all the treatments except control $\left(\mathrm{T}_{16}\right)$ where the lowest value was obtained.

\section{Economics}

Highest cost of cultivation ( $₹$ 36458/-) was registered in plots received 100\% RDN through FYM along with liquid manure top dressing twice at 25 and 50 DAT $\left(\mathrm{T}_{8}\right)$ and lowest cost of cultivation (₹ 24758/-) was in control plots $\left(\mathrm{T}_{16}\right)$ during the period of investigation.

Table 3: Economics of aromatic rice as influenced by organic nutrient management (Mean of 2 years)

\begin{tabular}{|c|c|c|c|c|}
\hline Treatments & Cost of cultivation $(₹ / \mathrm{ha})$ & Gross return (₹/ha) & Net return (₹/ha) & B:C ratio \\
\hline $\mathrm{T}_{1}: \mathrm{FYM} 100 \% \mathrm{RDN}$ & 35438 & 57897 & 22459 & 0.63 \\
\hline $\mathrm{T}_{2}: \mathrm{CM} 100 \% \mathrm{RDN}$ & 32638 & 61846 & 29208 & 0.89 \\
\hline $\mathrm{T}_{3:} \mathrm{PM} 100 \% \mathrm{RDN}$ & 30238 & 65910 & 35672 & 1.18 \\
\hline $\mathrm{T}_{4}: \mathrm{FYM} 50 \% \mathrm{RDN}+\mathrm{CM} 50 \%$ RDN & 34038 & 53968 & 19930 & 0.59 \\
\hline $\mathrm{T}_{5}: \mathrm{FYM} 50 \% \mathrm{RDN}+\mathrm{PM} 50 \% \mathrm{RDN}$ & 32838 & 59333 & 26495 & 0.81 \\
\hline $\mathrm{T}_{6}: \mathrm{PM} 50 \% \mathrm{RDN}+\mathrm{CM} 50 \%$ RDN & 31438 & 61048 & 29610 & 0.94 \\
\hline $\mathrm{T}_{7}: \mathrm{FYM} 1 / 3^{\text {rd }} \mathrm{RDN}+\mathrm{CM} 1 / 3^{\text {rd }} \mathrm{RDN}+\mathrm{PM} 1 / 3^{\text {rd }} \mathrm{RDN}$ & 32771 & 54824 & 22053 & 0.67 \\
\hline $\mathrm{T}_{8}: \mathrm{T}_{1}+\mathrm{Top}$ dressing with liquid manure & 36458 & 58709 & 22251 & 0.61 \\
\hline $\mathrm{T}_{9}: \mathrm{T}_{2}+\mathrm{Top}$ dressing with liquid manure & 33658 & 62307 & 28649 & 0.85 \\
\hline $\mathrm{T}_{10}: \mathrm{T}_{3}+\mathrm{Top}$ dressing with liquid manure & 31258 & 68960 & 37702 & 1.21 \\
\hline $\mathrm{T}_{11}: \mathrm{T}_{4}+\mathrm{Top}$ dressing with liquid manure & 35058 & 56709 & 21651 & 0.62 \\
\hline $\mathrm{T}_{12}$ : $\mathrm{T}_{5}+\mathrm{Top}$ dressing with liquid manure & 33858 & 59734 & 25876 & 0.76 \\
\hline $\mathrm{T}_{13}: \mathrm{T}_{6}+\mathrm{Top}$ dressing with liquid manure & 32458 & 61498 & 29040 & 0.89 \\
\hline $\mathrm{T}_{14:} \mathrm{T}_{7}+\mathrm{Top}$ dressing with liquid manure & 33791 & 56953 & 23161 & 0.69 \\
\hline $\mathrm{T}_{15}: 80: 40: 40 \mathrm{RDF}$ & 30758 & 69374 & 38616 & 1.26 \\
\hline $\mathrm{T}_{16}$ : Control & 24758 & 42019 & 17261 & 0.70 \\
\hline
\end{tabular}

Maximum gross return of ₹ 69374/ha and net return of ₹ 38616/ha with $\mathrm{B}: \mathrm{C}$ ratio 1.26 was realized from rice grown with $100 \%$ RDF chemical fertilizer $\left(\mathrm{T}_{15}\right)$ followed by the best organic practice i.e poultry manure + liquid manure top 
dressing twice at 25DAT and 50DAT $\left(\mathrm{T}_{10}\right)$ with values ₹ $68960 /$ ha, ₹ 37702/ha and 1.21 respectively. Further application of chemical fertilizer $\left(\mathrm{T}_{15}\right)$ gave $2.42 \%$ higher net return than poultry manure application $\left(\mathrm{T}_{10}\right)$. Similarly, application of Poultry manure with liquid manure $\left(\mathrm{T}_{10}\right)$ gave $31.6 \%$ and $69.4 \%$ higher net return than application of concentrated manure with liquid manure $\left(\mathrm{T}_{9}\right)$ and FYM with liquid manure $\left(\mathrm{T}_{8}\right)$ respectively. The lowest net profit was obtained from the treatments without supplementation of any fertilizer or manure $\left(T_{16}\right)$ to rice $₹ 17261 /$ ha. In the long run, organic cultivation might be more beneficial compared with conventional, because it has the potential to deliver a sustainable economic yield with low cost inputs over the years ${ }^{[11]}$.

\section{Conclusion}

Geetanjali rice grown organically with poultry manure alone or in combination with liquid manure i.e. PM $100 \%$ RDN + Top dressing with liquid manure at 25 and 50 DAT was found to be the most suitable organic nutrient management system not only for higher growth and productivity but also for generation of higher returns. Application of recommended dose of chemical fertilizer to aromatic rice recorded the higher productivity and profit during two years of study but the adaptation of organic nutrient management practices in community approach basis can enhance the farmers' income in long run sustaining the productivity and profitability.

\section{References}

1. Singh RP, Singh N, Mehta S, Godara AK. Adoption of fertilizers and weedicides in basmati paddy crop in Kurukshetra Distt. (Haryana). Agricultural Science Digest 2008;28(1):36-38.

2. Murali MK, Setty RA. Grain yield and nutrient uptake of scented rice mvariety, Pusa Basmati-1, at different levels of NPK, vermicompost and triacontanol. Oryza 2001;38(1\&2):84-85.

3. Yadav AK. Organic Agriculture (Concept, Scenario, Principals and Practices), National Centre of Organic Farming Department of Agriculture and Cooperation, Ministry of Agriculture, Govt. of India, Ghaziabad, Uttar Pradesh 2015.

4. Arif M, Tasneem M, Bashir F, Yaseen G, Iqbal RM. Effect of integrated use of organic manures and inorganic fertilizers on yield and yield components of rice. Journal of Agricultural Research 2014;52(2):197-206.

5. Hasanuzzaman M, Ahamed KU, Rahmatullah M, Akhter N, Nahar K, Rahman ML. Plant growth characters and productivity of wetland rice (Oryza sativa L.) as affected by application of different manures. Emirates Journal of Food and Agriculture 2010;22(1):46-58.

6. Sangeetha SP, Balakrishnan A, Bhuvaneswari J. Organic nutrient sources on growth and yield of rice. Madras Agricultural Journal 2010;97(7-9):251-253.

7. Goutami N, Rao CS, Sireesha A, Rao CP, Vijaya Gopal A. Effect of Long-Term Use of Inorganic Fertilizers, Organic Manures and Their Combination on Soil Properties and Enzyme Activity in Rice-Rice Cropping System. International Journal of Current Microbiology and Applied Science 2018;7(9):469-486.

8. Sujatha V, Mosha K, Subbaiah G, Rani PP. Residual soil fertility and productivity of rice (Oryza sativa L.) as influenced by different organic sources of nitrogen. International journal of plant, animal and environmental sciences 2014;4(1):266-269.
9. Kumari N, Singh AK, Pal SK, Thakur R. Effect of organic nutrient management on yield, nutrient uptake and nutrient balance sheet in aromatic rice (Oryza sativa). Indian Journal of Agronomy 2010;55(3):220-223.

10. Devegowda G. Poultry manure Excreta and other wastes as a source of Organic manures In: Training Course on Organic Farming, UAS, GKVK, Bangalore 1997, 7-11.

11. Bagchi TB, Ghosh A, Kumar U, Chattopadhyay K, Sanghamitra P, Ray S et al. Comparison of nutritional and physicochemical quality of rice under organic and standard production systems. Cereal Chemistry 2016;93(5):435-443. 